\title{
Study of Factors Affecting Saudi-Iranian Relations and Conflicts and Their Resulting Behavior Pattern
}

\author{
Mahdi Alikhani ${ }^{1} \&$ Mehdi Zakerian ${ }^{1}$ \\ ${ }^{1}$ Department of International Relations, College of Law \& Political Science, Science and Research Branch, \\ Islamic Azad University, Tehran, Iran \\ Correspondence: Mehdi Zakerian, Science and Research Branch, Islamic Azad University, Tehran, Iran. E-mail: \\ zakerian.m93@gmail.com
}

Received: May 17, 2016 Accepted: June 3, 2016 Online Published: August 30, 2016

doi:10.5539/jpl.v9n7p178 URL: http://dx.doi.org/10.5539/jpl.v9n7p178

\begin{abstract}
Relations between Tehran and Riyadh as two key players and two regional powers are of great importance. Special place of the two countries has caused relations between them to be very important in the formation of regional order in the Persian Gulf, the Middle East and Mediterranean area. Different behavior patterns in their relationship have taken place from the beginning of the relationship till now. After domestic, regional and international developments in 1999, Tehran and Riyadh went from divergence to the détente, coexistence and cooperation during the presidency of Hashemi Rafsanjani and Mohammad Khatami. However, since 2005 these two great neighboring countries again entered the competition, tensions and divergences. In this descriptive study, by using library method and reviewing online available resources conducted on Saudi-Iranian relations, our purpose is to investigate what were the effective factors in shaping the relations and conflicts between Iran and Saudi Arabia before the time Saudi Arabia cut diplomatic relations with Iran over the storming of the Saudi embassy in Tehran, and what behavior pattern these factors led to? According to results we found out that identical, geopolitical, and structural factors were the determinant factors in creating relations and conflicts between the two countries. Identity of Iran's political system is referred to Iranian-Islamic identity, while Saudi Arabia has Arabic-Islamic identity. Their geopolitical distinctions are related to Shiite and Sunni disciplines, and in terms of structure, rapprochement with U.S. and distribution of power in the Persian Gulf region are the most important indicators. These factors formed a "competitive conflict" behavior pattern among them.
\end{abstract}

Keywords: international relations, Middle East, Iran, Saudi Arabia, identity, conflicts

\section{Introduction}

The relation between Tehran and Riyadh as the key actors and regional powers assumes a great importance. The special place of both countries has led their relations to be of great importance in keeping the Persian Gulf, the Middle East and even the Mediterranean basin in order. With a glance at the Tehran-Riyadh relation, we are witnessing an array of competitions, and ups and downs not only in the aftermath of the Islamic Revolution in 1979, but we can also see it in the Pahlavi Period, in the course of the cooperation and solidarity of the two countries, in the form of Nixon-Kissinger doctrine. The Islamic Republic of Iran and Saudi Arabia have turned into their own natural rivals due to their "identity-related", "geopolitical", and "structural" characteristics, as there have been various behavioral schemes in their relationship from the beginning until now. Although, both countries have experienced highly strained relationships in the aftermath of the Revolution and the war between Iran and Iraq, Tehran and Riyadh moved from divergence toward détente, coexistence, and subsequently cooperation during the presidency of Hashemi Rafsanjani and Mohammad Khatami. With such friendly relationship since 2005, the two big neighboring countries have now fall back onto their tense, divergent relationship and competition.

The purpose of the study is to theoretically review the problem "which factors are determinant in forging the relations between the Islamic Republic of Iran and Saudi Arabia? and what kind of behavioral pattern exist in this relations?

\subsection{Previous Studies}

With regard to the background and literature of the research, a number of books, journals have been published 
concerning Iran-Riyadh relationships, some of which bear resemblance to the present work in terms of time. One of them was written by Wehrey et al. in 2009. The work revolves around Tehran-Riyadh relations after the fall of Saddam, as its contributors believe that the relationship exists in the center of much important political development in the Middle East Region, especially since the collapse of Saddam. They found that the change in diplomatic and economic arrangements in the Persian Gulf, political developments in Lebanon, the continuing conflict over Palestine and the conflict over Iran's nuclear program can be viewed as the most contributing factors in the two countries' relations (Wehrey et al. 2009). Also, in another work written by Terrill (2011), the author believes that Iran and Saudi Arabia have been rivals to one another for gaining influence over the Middle East region and the Persian Gulf at least since the Islamic Revolution. He points that U.S. is the most serious rival militia for Iran (Terrill, 2011).

Among well-known but older work is conducted by Chubin \& Tripp (1996). The authors studied Iran and Saudi Arabia dispute, including regional security, ideological competition (called Islamic Cold War), and petroleum policies, and claim that Saudi Arabia's behavior was a reaction to Iran's actions. In another study done by Furtig in 2002, he writes that Iran's efforts to play a role in Muslim communities challenged the position of Saudi Arabia (Furtig, 2002).

Concerning the works, the cause of tension and conflict between Tehran and Riyadh has been mostly focused on a particular factor; disruption to the balance of power with the fall of Saddam, the structural role of the United States, ideological rivalry or the Islamic Cold War, and regional issues and topics. While contributors obviously view the relations and behavioral patterns, governing them as interactions between internal (identity-related), regional (geopolitical), and structural (international) point of views with a mutual approach between Tehran and Riyadh, there are considerable differences between the present article and similar examples due to the theoretical framework employed (i.e. constructivism and neo-realism).

\section{Literature Review}

The true understanding and explanation of the relations between Iran and Saudi Arabia are not possible without attention to social and material factors governing this relation, and creating behavioral patterns. So, in this study, a combination of material (neorealism) and social (constructivism) approaches which are for power distribution and understanding the identity of actors, are used.

\subsection{Constructivism}

Despite their wide range of activities, constructivists have ideas ontologically close to one another. Metaphysical discussions constitute constructivist views, which can be outlined in three axes; (1) paying attention to social and normative structures along with material factors, conceptualization of material resources based on these structures, and attribution of the structures to actors' identity. Forming identity and special benefits, the social structures make actors' action feasible (Wendt, 1995), (2) the importance and the role of identity in making benefits and interactions, and (3) mutual interaction between structure and agent, which lead to the creation of social structures based on which identity and interest are defined.

Meanwhile, a central issue of constructivists is that of identity. According to Wendt, identity is specific characteristic of intended actors, which cause their motivational and behavioral tendencies. Identity rooted in an actor's self-understanding. When it comes to identity, two types of ideas should be noted; self's and other's. Internal and external ideas and structures both are build our identity (Wendt, 1999). Countries' identity and interests are closely intertwined. According to Wendt, "identities are the base of benefits" (Wendt, 1992), as countries determine their own benefit based on their identity, so their national role is ensured in this regard.

\subsection{Neorealism}

Neorealism or structural realism is a theory predominantly raised in Kenneth Waltz's views. Waltz proposed classic realism principles to obviously delineate the impact of international system structure on state behavior in a new fashion (Baldwin, 1993), setting his analysis level on international system.

In ontological dimension, Waltz (1979) finds states real actors in the international system, Waltz turns his focus toward the structural characteristics of international system rather than its components. His focus in pursuit of power on the part of states is anarchy. The anarchy remains at structural level because it makes the concern with security dominated by states as it prevents their functional differentiation. in dimension of Epistemology, system structure and distribution of material capabilities among governments are as key factors in understanding world policies (Mearsheimer, 1995), which forms the core of study based on this view. 


\section{Impact of Spiritual and Material Structures on the Relations Between Iran and Saudi Arabia}

After about a decade of tension and divergence in Iranian-Saudi relations subsequent to the Islamic Revolution of Iran in 1979, the two countries managed to move toward coexistence and the subsequent bilateral and regional cooperation. However, identity-related, geopolitical, and structural variations at internal, regional, and international levels have led Iran and Saudi Arabia to fall back on tension and divergence in their relationship. For material structures, structural characteristics of the international system and how power is distributed in the world, as well as the geopolitical characteristics in the Middle East and the Persian Gulf, and for spiritual structures, normative and identity-related developments will be discussed.

\subsection{Identity Confrontation; From Bilateral Relationship to Regional Level}

Identity-related developments affecting Iranian-Saudi relations during 2005-2013 have resulted from identity-related variation in Iran and Saudi Arabia, as well as identity-related developments in the Middle East Region. The rise of Mahmoud Ahmadinejhad, the new president of Iran, in 2005 not only resulted in a evolution in domestic political arena, but it also brought about a complete transformation in regional and international approaches, exhibiting a new picture of Iran inspired by transnational and Islamic thoughts. According to this, revolutionary, Islamic, and non-aligned dimensions of Iran identity partially stabilized during the Presidencies of Hashemi Rafsanjani and Mohammad Khatami become more highlighted than ever.

Seeking justice, bringing peace and avoiding threat were seen as the three important foreign policy elements of the Iranian government by the new president according to honor, interest, and wisdom. Influenced by the ideas and interpretations of the new government, the nature of the government within the Islamic-Shiite ideology framework was defined in this period and the Islamic Republic took on a totally religious and Islamic nature. According to this, the Islamic Republic is considered an Islamic and divine state, the special duty of which is to administer justice and promote it at national and international levels. As a result, the element "building identity" which defines "self" and "other" is Islam and the Islamic Revolution. Relying on this consideration and interpretation, the look at the international system is being totally evolved, and the ongoing system is considered illegitimate and unjust as its reformation, and existing arrangement change take priority. According to Ehteshami (2007), Mahmoud Ahmadinejad's stated policy aroused further suspicions about Iran's goals and incentives in the region.

On the other hand, the emergence of some regional developments, especially in Iraq and Lebanon, from 2006 onwards, and the reinforcement of the Shiites' place in the Middle East and the Persian Gulf, alignment of Iran's Islamic Shi'ite ideology among them, rendered the Shi'ite element more highlighted than ever for the Islamic Republic's identity. According to this, a close bond was formed between Iran and the countries with ideological affinity, namely Iraq, Syria, Lebanon, in support of Shiite population in Bahrain, and Saudi Arabia, which provoked negative reactions on the part of Arabs.

Identity redefinition and new interpretation of it among the ruling elite in Iran were in conjunction with identity redefinition and different interpretation of Saudi Arabia concerning "self" and "other". Uncertainty and confusion about the place and approaches of Iran's new president, as well as Iran's high profile peaceful nuclear program issue coincided with identity-related and ideological developments in the region, have led Saudi Arabia to change its approaches and turns. This change initiated in Iraq since the collapse of Saddam and deterioration of Sunni position among radical Wahhabi scholars was coincided with Saudi's view as it resulted in a different identity interpretation of the past.

A change in Iraq's domestic environment and the increase of Iranian influence in the country highlighted the element "Arabism" in Arab identity especially Saudi Arabia. With the rise of the Shiite in Iraq, and the rise of their influence in Lebanon, the issue highlighted the "Sunni" element among the Arabs and "Wahhabi" in Saudi Arabia.

Saudi Arabia's feeling of threatened because of identity development in the Middle East, particularly developments in Iraq and Lebanon, increased with the actions of the country scholars. Furthermore, in light of the developments in Iraq and Lebanon, unrest in the Arab world, the Wahhabi and Arabian elements allegedly threatened Saudi Arabia, which led the country to make a sensible decision about intensifying the chasm between the Shiite and the Sunni in an attempt to increase support for their allies and confront Iran and its allies (Gause, 2011). Accordingly, at this point in time in Saudi Arabia where King Abdullah officially rose to power as the king, we see a different perceptions of "self", Iran, and the Shiite on the part of Saudi Arabia. With the rise of King Abdullah, some extremist and Anti-Shiite figures as well as Iran gained considerable power in Saudi Arabia. 


\subsection{Connection between the Persian Gulf and Mediterranean Region in Geopolitical Competition}

One of the most important geopolitical features and distinctions of Iran, Shiite and Saudi Arabia, is Sunni Sect with Wahhabi interpretation. Accordingly, important geopolitical developments during 2005-2012, such as the promotion of the Shiite position in regional policy, the issue of Iran's nuclear program and unrest in the Arab world knows as Arabic Spring, had close link with Tehran and Riyadh's geopolitical distinctions. The developments gave rise to rivalries between Iran and Saudi Arabia in the Middle East and the Persian Gulf as it became prominent in four specific areas, namely Iraq, Lebanon, Bahrain, and Syria. The crucial feature of these areas was the Persian Gulf and the Mediterranean Region connection in the form of Tehran and Riyadh's regional rivalry. The significance of either region to the stability and security of the Persian Gulf and the Middle East caused the rivalry not to be restricted to regional actors, as a wide range of regional and trans-regional actors were included. The initial development was the promotion of the Shiite in the regional policies to the benefit of Iran. The fall of Saddam and the rise of the Shiite in Iraq and Hezbollah's victory over Israel in 2006 assumed a leading role in strengthening and consolidating the Shiite's position and place in the region, and therefore the promotion of Iran's position. The significance of 2006 war lay in the fact that the region were experiencing critical conditions; the rise of the Shiite in Iraq and the fragile state of the country because of sectarian violence, especially since early 2005, the rise of Hamas in Palestine, the long-run fight against Al-Qaeda in Afghanistan and Pakistan, Taliban insurgency, the Arab's concern with the growing influence of the Shiite among the Arabian Peninsula and the Mediterranean Region (Ehteshami, 2007), all of which were the events that expressed various actors' sensitivity to the transitions in the region.

The Arab leaders' concern revolved around the highlight of the Shiite element, the alliance between Iran and Iraq, the disruption to the power structure of the region to the disadvantage of traditional societies, building a coalition against the ongoing policies and order in the region, as well as a threat to the radical states in the region in terms of an influence over the Shiite minorities and challenging the legitimacy of the enclosed Sunni systems in the region (Barzgar, 2007).

The issue of Iran's nuclear program as an important geopolitical concern in this period was linked with geopolitical and structural dimensions as well as identity-related dimension inside Iran. In addition, the clash of regional transition and the escalating challenge of nuclear issue between Iran and the West were among the reasons for the conservative Arab to resort to a Shiite Crescent, as well as a reason for disturbing the regional power balance. Unrest in the Arab world as another important development invoked the rivalry between Saudi Arabia and Iran more than ever. While in the beginning Saudi Arabia's interpretation of new instabilities was based on a perception of threat, Iran perceived them as a new opportunity for itself. As a result of this, Iran set out to support the development of the status quo in Tunisia, Egypt, Bahrain, while Saudi Arabia was in support of its stability and that of allies in the Persian Gulf Cooperation Council, maintained the status quo versus the turmoil, and supported the unrest in Syria on the contrary, and extended the financial and military support to the Syrian opposition from a diplomatic level (Cordesman et al. 2011).

By international spread of Iranian influence since 2006, the foundations for an issue called threat equilibrium was provided. The Islamic Republic of Iran and its regional allies including countries (Iran, Iraq, and Syria) or non-governmental actors (Hezbollah and Hamas) were declared to be the threatening force according to Arabs and U.S. In this space, the state-space triangle formed that was able to exert influence over the Persian Gulf and the Middle East; therefore, an unwritten alliance of the United States, the Arab, and Israel was forged against Iran. However, in contrast to the past, Saudi Arabia abandoned its defense policies and adopted invasive policies, especially after the developments in Iraq at the height of the Arab world's unrest. Saudi Arabia's actions in Iraq, Bahrain, and Syria assumed a crucial role in promoting sectarianism and religious conflict in the region.

As opposed to Saudi Arabia, Iran played an active role for regional developments, ranging from Iraq to Lebanon. As a result of such functionality, the two axes "the Shiite-Sunni" led by Iran and Saudi Arabia were in completion and conflict with each other. Domestic and regional developments of this period have led Iran to take a turn different from the past in the Persian Gulf and the Middle East. Influenced by key regional and international developments, Saudi Arabia attempted to establish "its contribution as a regional coordinator and consensus builder through adopting a deft diplomacy" (Kamrava, 2012).

\subsection{Structural Focus among the Centers of the International System Power}

Coinciding with the second term of the presidency of George W. Bush in 2006, in the National Security Strategy of America, strengthening alliances to fight with global terrorism, preventing attacks against U.S. and its friends, as well as prohibition of threatening U.S., its allies, and friends with weapons of mass destruction received a lot of attention. Ensuring Israel's security and promoting the Middle East's peace process, ensuring the free flow of 
oil, supporting regional allies, and attempting to subdue and isolate Iran and Syria were incorporated into Bush's priorities in the Middle East Region and the Persian Gulf. the emphasis on pursuing the nuclear program with world powers, and the extreme positions of the President against Israel, including the questioning of the Holocaust incident along with other developments, led George Bush to declare Iran in his National Security Strategy the most important threat to the U.S.in 2006. The tough situation of Iran and the U.S. relation was to such an extent that Saudi Arabia took advantage of the structural links with the dominant power in the international system, even taking action to build up its contact and relationships with other centers of power, especially in facilitating the process of pressing policies on Iran including oil sanctions.

Increasing pressure on Iran through the nuclear program has led Saudi Arabia and other conservative Arabs not to neglect the opportunity to establish an anti-Iranian coalition that even encompassed Israel indirectly. With the developments in Iraq, nuclear issue, the developments in Lebanon and the Middle East peace process, this issue gave rise to a new framework under the title of "realignment" proposed by Condoleezza Rice in January 2007, in order to subdue Iran and its allies in January 2007 (Ignatius, 2007). In this respect, Saudi Arabia could maintain its key position to Washington. As the central part of America's restriction strategy against Iran, the country came to the fore through the extensive use of financial resources and the application of a diplomatic situation to persuade Iran's regional and international activists (Wehrey, 2011). The ideological and geopolitical characteristics of Saudi Arabia have brought about a suitable opportunity to control Iran's power in the region. With the rise of Obama in the U.S., no interference came out in Riyadh-Washington relation. At this point, the close relationship between U.S., and Saudi Arabia with respect to Iran was to such an extent that Saudi Arabia, following USA's policies, took over the responsibility for filling the gap caused by Iran oil sanctions, and Riyadh and Washington jointly pursued the propaganda and diplomatic efforts against Iran under the pretext of assassinating Saudi ambassador in the United States. The structure of international system during the course of relationships was not only rest upon the continuation of the power base, the Unites States, but it was also ended up with the increase of pressure and restriction to Iran by focusing on the structure of the international centers of power. In addition to this, for the regional power structure, the distribution of power between Iran and Saudi Arabia in the Persian Gulf, between the two powers along with Turkey and Israel within an area beyond the Middle East Region was linked with seeking balance and formal and informal alliance-building versus other players.

\section{Conclusion}

The process of détente, coexistence, and cooperation between Iran and Saudi Arabia affected by identical, geopolitical and structural factors was changed after 2005 AD. With the rise of the new government of Iran and adoption of an invasive approach to foreign policy, justice and battle with the order and status quo at the regional and international level have taken priority. According to this, the revolutionary-Islamic dimension of Iran identity came to fore again. Furthermore, regional and geopolitical developments coupled with distrust and distance between Tehran and Riyadh relations, including the clash of identity elements in Iraq and Lebanon, coinciding with the project of fuelling fears of Iran's nuclear program, and resorting to Iran's nuclear program. As a result, Iran's and Saudi Arabia's interpretation of "self" and "other" changed. With the clash of the transitions and Iran's nuclear program, and the unrest in the Arab world-- including Bahrain, Syria--Saudi Arabia resorted to invasive approaches, particularly versus Iran and its allies, while strengthening structural links, and attempted to change the status quo to the disadvantage of Iran.

The Shiite Crescent, the issue of Iran's nuclear program, and the unrest in the Arab world, each of them encompass identity-related, geopolitical, and structural considerations that deepen the chasm between Tehran and Riyadh. At the international level, as the U.S. continues to play a structural role, with Obama's multi-objective approach-based structural centralization, the pressure on Iran mounted. At regional level where distrust and suspicion grew among actors, the structure of power was based on the rivalry between Iran and Saudi Arabia; it was shaped as mutual action and reaction between Iran and Saudi Arabia, Turkey and Israel, within a union framework because of fear of others at the Middle East level. As a result of bilateral and regional challenges between Tehran and Riyadh, Saudi Arabia following the West's diplomacy and oil policy increased the pressure on Iran through Iran's nuclear program. Hence Iran and Saudi Arabia have experienced one of the darkest times ever. As a result of the transitions, the discrepancies between Tehran and Riyadh echoed in the Mediterranean Basin, as well as the Persian Gulf, as they were directly connected to it.

For all major regional issues (Iraq, Bahrain, Yemen, Palestine, Lebanon, and Syria), three forgoing factors had contributing role, in the sense that ideological, geopolitical, and structural significance of each resulted in the complexity and connection with one another as well as other regional and trans-regional issues, thereby struggling for equilibrium both ideologically and materialically. The role of Iran in major developments in 2006 
and 2008, including Hezbollah's and Gaza's war with Israel, doubled the prominence of Iran's position concerning the Arab world's policies, as escalating the conflict with Saudi Arabia. On the one hand, the two countries came out in support of the status quo for their allies and friends; they backed up a change in the status quo for their rival's allies, on the other hand. By strengthening the logic of politics, power, and social structures, we found out that Iran and Saudi Arabia behaviors towards each other, due to their profound revisionism and allies, is based on identity conflict, distrust, unlimited political power, a zero-sum game, and as a result, a "competitive conflict" behavioral pattern.

\section{References}

Baldwin, D. A. (Ed.). (1993). Neorealism and Neoliberalism: The Contemporary Debate. New York: Columbia University Press.

Barzgar, K. (2007). Iran, Araghe Jadid, va Nezame Amniate Mantegheyie Khalije Fars[Iran, the new Iraq and the Persian Gulf regional security]. Rahbord, 43, 59-75. [in Persian]

Chubin, S., \& Tripp, C. (1996). Iran-Saudi Arabia Relations and Regional Order. London: Oxford University Press.

Cordesman, A. H., Alsis, P., \& Allison, M. (2011). US and Iranian Strategic Competition in the Gulf States and Yemen. Washington: Center for Strategic and International Studies.

Ehteshami, A. (2007). Iran's Political and Regional Relations: Post-Détente. Perceptions, 12(1), 29-44.

Furtig, H. (2002). Iran's Rivalry with Saudi Arabia Between the Gulf Wars (1st ed.). Berkshire: Garnet Publishing Limited.

Gause, F. G. (2007). Saudi Arabia: Iraq, Iran, the Regional Power Balance, and the Sectarian Question. Strategic Insights, 6(2). Retrieved from http://kms1.isn.ethz.ch/serviceengine/Files/ISN/30995/ ichaptersection_singledocument/799213cb-b04a-4611-92d0-aa77e5117f4b/en/3_gauseMar07.pdf

Ignatius, D. (2007, January 26). Rice's Strategic Reset. Washington Post. Retrieved from http://www.washingtonpost.com/wpdyn/content/article/2007/01/25/AR2007012501555.html

Kamrava, M. (2012). The Arab Spring and the Saudi-Led Counterrevolution. Orbis, 56(1), 96-104. http://dx.doi.org/10.1016/j.orbis.2011.10.011

Mearsheimer, J. J. (1995). A realist reply. International Security, 20(1), 82-93. http://dx.doi.org/10.2307/2539218

Terrill, W. A. (2011). The Saudi-Iranian Rivalry and the Future of Middle East Security. Pennsylvania: Strategic Studies Institute (SSI).

Waltz, K. N. (1979). Theory of International Politics. New York: Random House.

Wehrey, F. (2011). Uprisings Jolt the Saudi-Iranian Rivalry. Current History, 110(740), 352.

Wehrey, F., Karasik, T. W., Nader, A., Ghez , J., Hansell, L., \& Guffey, R. A. (2009). Saudi-Iranian Relations since the Fall of Saddam: Rivalry, Cooperation, and Implications for U.S. Policy. Santa Monica: RAND Publishing.

Wendt, A. (1992). Anarchy is what States make of it: The Social Construction of Power Politics. International Organization, 46(2), 391-425. http://dx.doi.org/10.1017/S0020818300027764

Wendt, A. (1995). Constructing International Politics. International Security, 20(1), 71-81. http://dx.doi.org/10.2307/2539217

Wendt, A. (1999). Social Theory of International Politics. Cambridge: Cambridge University Press. http://dx.doi.org/10.1017/CBO9780511612183

\section{Copyrights}

Copyright for this article is retained by the author(s), with first publication rights granted to the journal.

This is an open-access article distributed under the terms and conditions of the Creative Commons Attribution license (http://creativecommons.org/licenses/by/4.0/). 